Syntax Fusion: Jurnal Nasional Indonesia

e-ISSN: 2775-4440

Vol. 1, No. 10, Oktober 2021

\title{
ANALISIS PENGARUH PROFITABILITAS DAN SOLVABILITAS PERUSAHAAN TERHADAP INITIAL RETURN PADA PENAWARAN SAHAM PERDANA
}

\author{
Frans Yohanes \\ Universitas Widyatama, Indonesia \\ Email: deecaprios@gmail.com
}

\begin{abstract}
Abstrak
Secara teoritis, penerbitan saham di pasar perdana dapat menimbulkan kemungkinan penerbitan harga, yaitu apakah harga emisi terlalu tinggi atau terlalu rendah. Salah satu cara untuk memperoleh tambahan modal dalam rangka pembiayaan perusahaan yang sedang tumbuh atau pengembangan usaha adalah dengan go public. Selain digunakan untuk ekspansi, hasil pencatatan juga dapat digunakan untuk melunasi hutang. Akhirnya, sambil memperkuat struktur permodalan, dana tersebut diharapkan dapat lebih meningkatkan situasi keuangan perusahaan. Penelitian ini bertujuan untuk menganalisis pengaruh profitabilitas dan solvabilitas perusahaan terhadap imbal hasil penawaran umum perdana. Metode penelitian yang digunakan dalam penelitian ini adalah metode analisis deskriptif kuantitatif. Metode analisis yang digunakan dalam penelitian ini adalah analisis regresi linier berganda, dengan menggunakan software SPSS for windows untuk mengolah data sekunder. Hasil penelitian menunjukkan bahwa profitabilitas perusahaan terbukti berpengaruh terhadap pendapatan awal, dan tidak terbukti bahwa solvabilitas perusahaan berpengaruh terhadap pendapatan awal.
\end{abstract}

Kata Kunci: Analisis Regresi; Deskriptif Kuantitatif; Profitabilitas; Pengembalian Awal.

Diterima: 24-09-2021 Direvisi: 15-10-2021 Disetujui: 18-10-2021

\section{Pendahuluan}

Salah satu cara untuk memperoleh tambahan modal dalam rangka pembiayaan perusahaan yang sedang tumbuh atau pengembangan usaha adalah dengan go public. Selain digunakan untuk ekspansi, hasil pencatatan juga dapat digunakan untuk melunasi hutang. Akhirnya, sambil memperkuat struktur permodalan, dana tersebut diharapkan dapat lebih meningkatkan situasi keuangan perusahaan (Gerianta, 2008).

Penawaran umum perdana merupakan salah satu aksi korporasi suatu perusahaan, yang tujuannya adalah untuk memperoleh dana dari masyarakat untuk kepentingan terus beroperasinya perusahaan (Manurung, 2012). Perusahaan yang mengeluarkan saham ke publik bisa berkali-kali mengeluarkan saham, namun di Indonesia hanya BNI yang 
melakukan IPO kedua (secondary IPO). Beberapa negara dengan bursa maju biasanya melakukan beberapa IPO.

Selama proses pencatatan sebelum saham diperdagangkan di pasar sekunder (bursa saham), saham dijual di pasar perdana, yang biasa disebut dengan initial public offering (IPO). Harga saham di pasar perdana (pada saat penawaran umum perdana) telah ditentukan sebelumnya, sedangkan harga di pasar sekunder ditentukan oleh mekanisme pasar, yaitu hubungan antara penawaran dan permintaan. Dalam dua mekanisme penetapan harga ini, seringkali terjadi perbedaan harga antara pasar perdana dan pasar sekunder untuk saham yang sama (Gerianta, 2008).

Menurut Beatty, jika harga saham pada saat IPO jauh lebih rendah dari harga di pasar sekunder pada hari pertama, maka akan terjadi underpricing. Sebaliknya, jika harga pada saat IPO secara signifikan lebih tinggi dari harga di pasar sekunder pada hari pertama, maka dikatakan terlalu mahal (Beatty, 1989).

Secara teoritis, penerbitan saham di pasar perdana dapat menimbulkan kemungkinan penerbitan harga, yaitu apakah harga emisi terlalu tinggi atau terlalu rendah. Untuk mengetahui apakah saham perdana yang diterbitkan overprice atau underprice, dijelaskan dua alternatif metode di bawah ini, yaitu perbandingan harga teoritis dari estimasi saham dengan harga pasar perdana. Jika harga di pasar perdana lebih tinggi dari harga teoritis, saham dianggap terlalu mahal. Sebaliknya, jika lebih rendah, itu diklasifikasikan sebagai underpriced.

Selanjutnya pertimbangkan faktor risiko dan bandingkan tingkat keuntungan yang diperoleh dari saham yang baru dijual. Jika tingkat keuntungan yang diperoleh lebih tinggi dari tingkat keuntungan yang diharapkan, berarti nilai saham tersebut dinilai terlalu tinggi. Sebaliknya, jika tingkat keuntungan yang diperoleh lebih rendah dari tingkat keuntungan yang diharapkan, maka harga saham akan rendah (Hanafi \& Husnan, 1991). Hasil penelitian berbagai negara menunjukkan bahwa initial rate of return selalu positif, meskipun rata-rata rate of return di atas $10 \%$, seperti terlihat pada Tabel 1. Tingkat pengembalian awal yang positif ini karena harga saham IPO terlalu murah.

Penelitian ini mereplikasi penelitian yang dilakukan oleh (Suyatmin \& Sujadi, 2007) yang mempelajari faktor-faktor yang mempengaruhi underpricing dalam IPO perusahaan manufaktur di Bursa Efek Jakarta dari tahun 1999 hingga 2003. Variabelvariabel yang mempengaruhi underpricing adalah: umur perusahaan, ukuran perusahaan, reputasi auditor, reputasi penjamin emisi, jenis industri, laba per saham, skala penerbitan, rasio lancar, laba atas investasi dan leverage keuangan. Adapun perbedaan dari penelitian sebelumnya, penelitian ini menggunakan sampel dari perusahaan manufaktur dan LQ45, dan periode penelitian dari tahun 2009 sampai dengan tahun 2014. Variabel yang digunakan antara lain: rasio profitabilitas dan rasio solvabilitas perusahaan.

\section{Metode Penelitian}

Penelitian ini menggunakan metode analisis deskriptif kuantitatif, yang bertujuan untuk menjelaskan atau mendeskripsikan secara kuantitatif kejelasan pengaruh antar variabel. Objek penelitian ini adalah seluruh perusahaan manufaktur dan perusahaan 
LQ45 yang terdaftar di Bursa Efek Indonesia untuk pertama kali antara tahun 2009 sampai dengan tahun 2014. Total populasi adalah 113 perusahaan. Setelah kriteria pemilihan sampel untuk semua perusahaan LQ45 diperoleh sampel sebanyak 30 perusahaan LQ45.

Variabel yang dianalisis dalam penelitian ini meliputi variabel bebas (X) yang terdiri dari profitabilitas perusahaan, yaitu profitabilitas perusahaan adalah informasi tentang profitabilitas perusahaan. Informasi ini akan memberikan informasi kepada pihak luar tentang efektivitas operasi perusahaan. Profitabilitas perusahaan yang tinggi akan mengurangi ketidakpastian IPO sehingga mengurangi tingkat underpricing (Hidayati dan Indriantoro, 1998). Kemudian ada variabel dependen (Y), yaitu initial return (IR). Pengembalian awal adalah selisih antara harga penawaran umum dan harga penutupan kedua pada hari pertama.

Data yang digunakan dalam penelitian ini adalah data bekas. Data bekas adalah data yang diperoleh dari pihak lain yang terlebih dahulu mengumpulkannya. Uji $\mathrm{F}$ digunakan untuk menguji secara simultan signifikansi pengaruh profitabilitas perusahaan dan rasio solvabilitas terhadap initial return (IPO). Uji t digunakan untuk menguji signifikansi pengaruh profitabilitas perusahaan dan rasio solvabilitas perusahaan terhadap penawaran umum perdana (Grinblatt, 1989).

\section{Hasil Dan Pembahasan}

\section{A. Hasil Penelitian}

Tabel 1 menunjukkan bahwa selama periode penelitian 2009-2014, rata-rata hampir semua emiten yang melakukan penawaran umum perdana (IPO) mengalami berbagai tingkat underpricing, seperti initial return (IR) yang positif. Secara keseluruhan, rata-rata harga penawaran awal selama masa studi (Harga Penawaran) adalah 931, dan harga penutupan pasar sekunder adalah 1110 . Ada perbedaan positif $21,5 \%$ antara harga penutupan dan harga penerbitan, sehingga secara keseluruhan menghasilkan nilai ratarata. Pengembalian awal yang positif karena harga penutupan lebih tinggi dari penawaran umum perdana.

\section{Tabel 1}

\section{Harga Penawaran Umum, Harga Penutupan di Pasar Sekunder dan Underpricing dari Perusahaan Manufaktur dan LQ 45 pada saat IPO}

\begin{tabular}{lccc}
\hline \multirow{2}{*}{ Variabel } & \multicolumn{3}{c}{ Statistik Deskriptif } \\
\cline { 2 - 3 } Offering Price & Tertinggi & Terendah & Rata-rata \\
\cline { 2 - 3 } & ICBP & STAR & \multirow{2}{*}{931} \\
\cline { 2 - 3 } Closing Price & 5,395 & 102 & \multirow{2}{*}{1,110} \\
\cline { 2 - 3 } & ICBP & STAR & \multirow{2}{*}{$21.5 \%$} \\
\cline { 2 - 3 } $\begin{array}{l}\text { Initial Return } \\
(\%)\end{array}$ & $\begin{array}{c}5,950 \\
\text { BJBR, VIVA } \\
\text { \& IMPC }\end{array}$ & SMBR & \\
\cline { 2 - 3 } & $50.0 \%$ & $1.8 \%$ & \\
\hline
\end{tabular}

Sumber: Data Sekunder yang Diolah 
Tabel 2 di bawah ini menunjukkan Return on Asset (ROA) dan Debt to Equity Ratio (DER) pada sampel perusahaan LQ45.

\section{Tabel 2}

Return on Asset (ROA) dan Debt to Equity Ratio (DER) dari Perusahaan Manufaktur dan LQ45

(Berdasarkan Laporan Keuangan Sebelum Listing)

\begin{tabular}{cccc}
\hline \multirow{2}{*}{ Variabel } & \multicolumn{3}{c}{ Statistik Deskriptif } \\
\cline { 2 - 3 } & Tertinggi & Terendah & Rata-rata \\
\hline \multirow{2}{*}{ ROA } & CINT & VIVA & \multirow{2}{*}{$9.7 \%$} \\
\cline { 2 - 3 } & $47.2 \%$ & $0.2 \%$ & \multirow{2}{*}{3.0} \\
\cline { 2 - 3 } DER & BBTN & BIPI & \\
\cline { 2 - 3 } & 13.6 & 0.1 &
\end{tabular}

Sumber: Data Sekunder yang Diolah

Kinerja keuangan suatu perusahaan merupakan informasi penting bagi investor untuk mengambil keputusan investasi. Kinerja keuangan yang baik akan menarik lebih banyak investor untuk berinvestasi, sehingga meningkatkan permintaan saham perusahaan. Akibatnya harga saham akan naik dan perubahan antar transaksi yang terjadi menjadi semakin kecil. Secara umum, ROA rata-rata adalah 9,7\% dan DER adalah 3,0.

\section{Tabel 3}

Normalitas Data Pada Perusahaan Manufaktur dan LQ45 Periode 2009-2014

One-Sample Kolmogorov-Smirnov Test

\begin{tabular}{llr}
\hline & & $\begin{array}{c}\text { Unstandardized } \\
\text { Predicted Value }\end{array}$ \\
\hline $\mathrm{N}$ & Mean & 30 \\
Normal Parameters,b & Std. Deviation & .2153333 \\
& Absolute & .07814668 \\
Most Extreme Differences & Positive & .131 \\
& Negative & .119 \\
Kolmogorov-Smirnov Z & & -.131 \\
Asymp. Sig. (2-tailed) & & .719 \\
\hline a. Test distribution is Normal. & & .680 \\
b. Calculated from data. & & \\
Sumber: Data Sekunder yang Diolah & \\
$\quad$ Berdasarkan hasil pada Tabel 3 di atas, data berdistribusi & normal. Hal ini \\
njukkan dengan nilai Kolmogorov - Smirnov sebesar 0,719 dan signifikansi sebesar
\end{tabular}


0,680 yang lebih besar dari 0,05 . Artinya data residual berdistribusi normal karena nilai signifikansinya lebih besar dari 0,05 .

\section{Gambar 1 \\ Normal Probability Plot Pada Perusahaan Manufaktur dan LQ45}

Normal P-P Plot of Regression Standardized

Residual

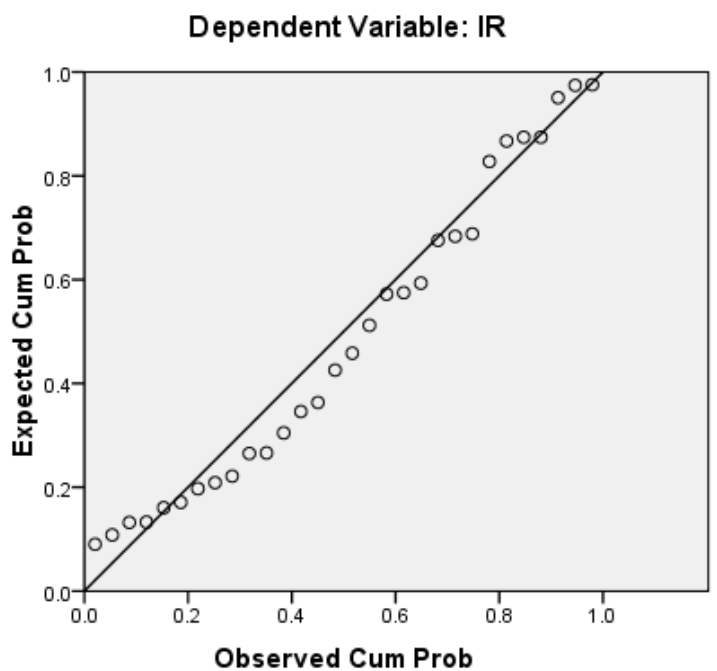

Dengan melihat histogram, dapat disimpulkan bahwa pola distribusi data mendekati normal. Kemudian pada grafik normal, Anda dapat melihat bahwa titik-titik distribusinya mendekati normal.

Hasil uji multikolinearitas pada perusahaan manufaktur dan LQ45 dapat dilihat pada Tabel 4 berikut.

\section{Tabel 4}

\section{Hasil Uji Multikolinearitas Pada Perusahaan Manufaktur dan LQ45}

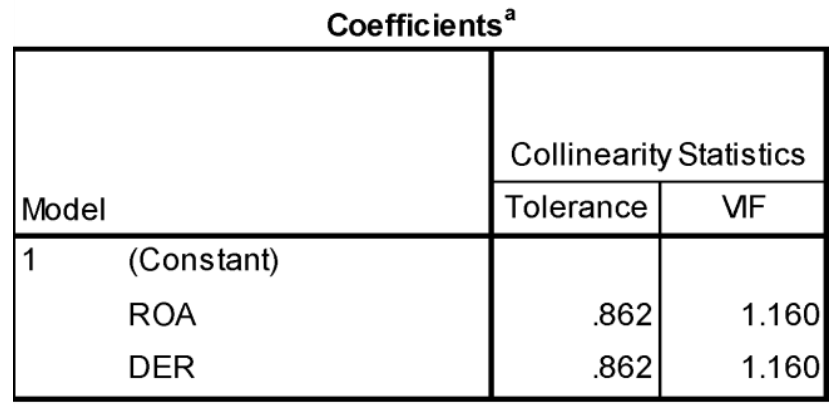

a. Dependent Variable: IR

Sumber: Data Sekunder yang Diolah

Pada model regresi LQ45, jika nilai tolerance lebih kecil dari 1 dan nilai VIF lebih kecil dari 10, maka dinyatakan tidak terjadi multikolinearitas. Dapat dilihat dari Tabel 4 bahwa nilai toleransi semua variabel bebas kurang dari 1 dan nilai VIF jauh lebih rendah 
dari 10. Hal ini menunjukkan bahwa tidak terjadi multikolinearitas pada model ini. Artinya tidak ada korelasi antara variabel bebas (independen).

\section{Uji Hipotesis}

Pengujian hipotesis dalam penelitian ini menggunakan analisis regresi berganda dengan bantuan software SPSS versi 22. Pilihan analisis ini adalah untuk mengukur kekuatan hubungan antara dua variabel atau lebih, sekaligus menunjukkan arah variabel bebas dari hubungan antara variabel terikat dan variabel terikat. Lakukan analisis regresi berganda melalui beberapa tahapan yang dijelaskan pada tabel berikut:

Tabel 5

Hasil Regresi Perusahaan LQ45

\begin{tabular}{|c|c|c|c|c|c|c|}
\hline \multicolumn{7}{|c|}{ Coefficients $^{\mathrm{a}}$} \\
\hline \multirow{2}{*}{\multicolumn{2}{|c|}{ Model }} & \multicolumn{2}{|c|}{$\begin{array}{l}\text { Unstandardized } \\
\text { Coefficients }\end{array}$} & \multirow{2}{*}{\begin{tabular}{|c}
$\begin{array}{c}\text { Standardized } \\
\text { Coefficients }\end{array}$ \\
Beta \\
\end{tabular}} & \multirow[b]{2}{*}{$t$} & \multirow[b]{2}{*}{ Sig. } \\
\hline & & $B$ & Std. Error & & & \\
\hline 1 & (Constant) & .332 & .056 & & 5.940 & .000 \\
\hline & ROA & -.750 & .288 & -.480 & -2.603 & .015 \\
\hline & DER & -.015 & .010 & -.271 & -1.468 & .154 \\
\hline
\end{tabular}

a. Dependent Variable: IR

Sumber: Data sekunder yang diolah

Dengan melihat Tabel 5 di atas, dapat disusun persamaan regresi linear berganda sebagai berikut: Initial Return $=0.332-0,750$ X1 - 0,015 X2

Nilai t hitung variabel profitabilitas perusahaan (ROA) pada perusahaan LQ45 sebesar -2,603 dan nilai signifikansi 0,015 yang signifikan pada taraf signifikansi 0,05 karena lebih kecil dari 0,05. Oleh karena itu, dapat diterima untuk mengasumsikan bahwa profitabilitas perusahaan (ROA) memiliki dampak yang signifikan terhadap pengembalian awal. Hasil yang diperoleh adalah nilai t hitung variabel solvabilitas perusahaan LQ45 sebesar -1.468 dan nilai signifikansinya sebesar 0,154 , nilai tersebut tidak signifikan pada taraf signifikansi 0,05 karena lebih besar dari 0,05. Oleh karena itu, asumsi bahwa solvabilitas perusahaan pada perusahaan manufaktur dan LQ45 berpengaruh signifikan terhadap pengembalian awal dapat ditolak.

1) Pengaruh Profitabilitas Perusahaan Terhadap Initial return $\left(\mathrm{H}_{1}\right)$.

Hipotesis pertama yang diajukan menyatakan bahwa profitabilitas perusahaan (ROA) berpengaruh terhadap initial return. Dari hasil penelitian diperoleh nilai t hitung variabel ROA perusahaan LQ45 sebesar -2,603 dan nilai signifikansi 0,015, nilai ini signifikan pada taraf signifikansi 0,05 karena lebih kecil dari 0,05. Oleh karena itu, dapat diterima untuk mengasumsikan bahwa ROA perusahaan LQ45 mempengaruhi pengembalian awal.

2) Pengaruh Solvability Ratio Terhadap Initial Return $\left(\mathrm{H}_{2}\right)$.

Hipotesis kedua yang diajukan menyatakan bahwa rasio solvabilitas (DER) berpengaruh terhadap pengembalian awal. Dari hasil penelitian diperoleh nilai t hitung variabel rasio solvabilitas perusahaan LQ45 sebesar -1,468 dengan nilai signifikansi 0,154 , diantara nilai tersebut tidak signifikan pada taraf signifikansi 0,05 karena lebih 
besar dari 0,05. Oleh karena itu, asumsi bahwa rasio solvabilitas perusahaan manufaktur dan LQ45 berdampak pada pengembalian awal dapat ditolak..

3) Pengaruh Profitabilitas perusahaan (ROA) dan Solvability Ratio (DER) Terhadap Initial Return $\left(\mathrm{H}_{3}\right)$.

Hipotesis ketiga yang diajukan menyatakan bahwa profitabilitas perusahaan (ROA) dan rasio solvabilitas (DER) juga berpengaruh terhadap initial return. Dari hasil uji F diperoleh nilai F hitung Perusahaan LQ45 sebesar 3,533 dan probabilitas sebesar 0,043. Karena probabilitasnya lebih kecil dari 0,05 atau 5\%, maka dapat diartikan bahwa profitabilitas dan solvabilitas perusahaan secara bersama-sama mempengaruhi pendapatan awal perusahaan manufaktur dan LQ45 yang melakukan penawaran umum perdana selama periode 2009-2014.

\section{B. Pembahasan}

\section{1) Pengaruh Profitabilitas Perusahaan Terhadap Initial return.}

Ada pengaruh antara jumlah ROA dan pengembalian awal. Hasil perhitungan regresi berganda dari koefisien ini adalah negatif, menunjukkan bahwa semakin tinggi ROA perusahaan maka semakin rendah tingkat pengembalian awal. Dengan kata lain, hasil penelitian ini juga menunjukkan bahwa investor cukup mempertimbangkan variabel ROA pembelian saham IPO saat memutuskan untuk berinvestasi. Dampak ROA (Corporate Profitability) terhadap imbal hasil awal dapat disebabkan oleh informasi keuangan yang diberikan oleh emiten melalui laporan keuangan yang telah diaudit.

Besarnya profitabilitas yang disajikan dalam laporan keuangan sudah cukup untuk menunjukkan bahwa perusahaan memiliki kinerja yang baik di mata investor. Hal ini juga mencerminkan bahwa investor mempertimbangkan tingkat ROA suatu perusahaan, karena ROA merupakan salah satu rasio laba, yaitu rasio yang menunjukkan seberapa efektif perusahaan beroperasi untuk menghasilkan laba atau keuntungan bagi perusahaan. ROA digunakan untuk mengukur efektivitas penggunaan aset perusahaan untuk menciptakan keuntungan. Semakin tinggi nilai ROA menunjukkan bahwa perusahaan memiliki kemampuan untuk menghasilkan laba di masa yang akan datang, dan laba merupakan informasi penting bagi investor untuk menanamkan modalnya (Agus Sartono, 2001).

Hasil penelitian ini mendukung hasil penelitian Yasa (2008), namun hasil tersebut tidak sejalan dengan penelitian sebelumnya yang dilakukan oleh Daljono (2000), dimana perusahaan IPO tidak menemukan rasio ROA perusahaan terhadap initial return. Hasil penelitian Daljono (2000) menunjukkan bahwa hanya variabel reputasi underwriter dan financial leverage yang secara statistik berpengaruh positif dan signifikan terhadap initial return.

\section{2) Pengaruh Solvability Ratio Terhadap Initial Return}

Investor berinvestasi di pasar sekunder untuk memperoleh pendapatan dan kurang memperhatikan informasi DER dalam laporan keuangan, karena investor percaya bahwa 
nilai DER sangat dipengaruhi oleh faktor eksternal perusahaan, daripada kinerja manajemen perusahaan..

Secara keseluruhan rata-rata DER dari 30 perusahaan sampel yang diteliti adalah 3. Hubungan dengan initial return tidak sesuai dengan teori yang menjadi dasar penelitian ini. Perusahaan dengan DER tinggi memiliki tingkat pengembalian awal yang lebih tinggi. Perbedaan dengan teori terlihat jelas dari data penelitian berikut ini:

1. Enam perusahaan atau $20 \%$ dari total perusahaan yang diteliti memiliki tingkat DER diatas 5 secara rata-rata nilai initial return-nya sebesar $22.6 \%$,

2. Tujuh perusahaan atau $23.3 \%$ dari total perusahaan yang diteliti memiliki tingkat DER 2 -5 secara rata-rata nilai initial return-nya sebesar $14.6 \%$,

3. 17 perusahaan atau $56.7 \%$ dari total perusahaan yang diteliti memiliki tingkat DER lebih rendah dari 2 secara rata-rata nilai initial return-nya sebesar $24.1 \%$.

Data di atas menunjukkan bahwa perusahaan dengan DER yang lebih rendah sebenarnya memiliki pengembalian awal yang lebih tinggi daripada perusahaan dengan DER yang lebih tinggi. Hasil penelitian ini sejalan dengan penelitian yang dilakukan oleh Kristiantari (2012), dimana ia gagal membuktikan bahwa debt-to-equity ratio (DER) berpengaruh terhadap initial return. Ini mungkin karena ketidakpercayaan investor terhadap informasi keuangan yang diberikan oleh penerbit.

\section{3) Pengaruh Profitabilitas Perusahaan dan Solvability Ratio Terhadap Initial Return.}

Hasil pengujian menunjukkan bahwa variabel ROA lebih dominan.Hasil kedua variabel independen yang diteliti secara bersama-sama terbukti berpengaruh terhadap initial return, namun pada uji t untuk masing-masing variabel independen hanya ROA yang terbukti memiliki pengaruh terhadap return awal berdampak pada pengembalian awal. Artinya tingkat pengembalian awal dipengaruhi oleh ROA perusahaan. Besarnya profitabilitas yang disajikan dalam laporan keuangan sudah cukup untuk menunjukkan bahwa perusahaan memiliki kinerja yang baik di mata investor.

Hal ini juga mencerminkan bahwa investor mempertimbangkan tingkat ROA perusahaan, sehingga pada saat memutuskan untuk membeli saham perdana, investor dapat mempelajari terlebih dahulu informasi dalam laporan keuangan terutama berupa rasio profitabilitas. Selain itu, perusahaan yang akan melakukan IPO juga perlu memperhatikan ROA perusahaannya terlebih dahulu, karena akan mempengaruhi daya tarik investor terhadap investasi perusahaannya.

Berbeda dengan rasio profitabilitas, investor percaya bahwa rasio solvabilitas perusahaan tidak cukup untuk menentukan pengembalian awal, karena investor percaya bahwa nilai DER sangat dipengaruhi oleh faktor di luar perusahaan, daripada kinerja manajemen perusahaan itu sendiri. Dari uji t terlihat bahwa rasio solvabilitas tidak berpengaruh terhadap initial return. Berdasarkan hasil tersebut, sebelum investor memutuskan untuk membeli saham perdana, sebaiknya terlebih dahulu mempertimbangkan faktor-faktor lain selain rasio DER, seperti jenis industri, laba per saham, laba, pertumbuhan laba, rasio lancar, ukuran perusahaan, usia perusahaan, 
reputasi auditor. Reputasi penjamin emisi, kondisi ekonomi, jenis penerbitan saham, leverage keuangan dan faktor non-keuangan lainnya.

Hasil penelitian ini menunjukkan bahwa rasio profitabilitas dan rasio solvabilitas yang diukur secara bersama-sama memiliki pengaruh terhadap tingkat pengembalian awal. Dengan menggunakan hasil pengujian SPSS 22 dapat ditunjukkan bahwa rasio profitabilitas memiliki persentase signifikansi yang lebih tinggi dibandingkan rasio solvabilitas, meskipun rasio solvabilitas belum terbukti terhadap pengembalian awal. Oleh karena itu, dapat dijelaskan betapa pentingnya variabel ROA terhadap tingkat pengembalian awal perusahaan IPO.

\section{Kesimpulan}

Profitabilitas (ROA) perusahaan berpengaruh terhadap pendapatan awal dan LQ45 perusahaan manufaktur selama periode 2009-2014. Hal ini dikarenakan ROA merupakan rasio yang menjelaskan tingkat profitabilitas suatu perusahaan. ROA menjelaskan efektivitas perusahaan dalam mengelola asetnya agar dapat menghasilkan keuntungan bagi pemegang saham.

Solvabilitas perusahaan tidak berpengaruh terhadap laba awal LQ45 2009-2014. Hasil penelitian menunjukkan bahwa rasio DER gagal meningkatkan tingkat pengembalian awal yang terjadi pada saat penawaran umum perdana (IPO). Profitabilitas dan solvabilitas perusahaan juga mempengaruhi hasil awal perusahaan manufaktur 20092014 dan LQ45. 


\section{BIBLIOGRAFI}

Achyani, Fatchan and, Dr. Mas'ud Machfoedz, MBA. 1999. "Analisis Informasi Prospektus yang Berpengaruh Terhadap Return Awal Penawaran Perdana di Bursa Efek Jakarta", Thesis. Google Scholar.

Agus Sartono. 2001. "Manajemen Keuangan Teori dan Aplikasi”. Yogyakarta: BPFEYogyakarta. Google Scholar.

Beatty, R.P. 1989. "Auditor Reputation and The pricing of Initial Public Offerings". The Accounting Review. Vol. LXIV. No. 4. October. Google Scholar.

Benveniste, L.M \& Spindt R.L. 1989. "How Investment Bankers Determine the Offer Price and Allocation of New Issue". Journal of Financial Economics, 24, 343361. Google Scholar.

Bower, Nancy L. 1989. "Firm Value and the Choice of Offering Method in Initial Public Offering". The Journal of Finance. Vol XLIV No 3, July, 647-662. Google Scholar.

Carter, R.B. \& S. Manaster. 1990. "Initial Public Offerings and Underwriter Reputation”. Journal of Financial. Vol. 45. Google Scholar.

Daljono. 2000. “Analisis Faktor-faktor yang Mempengaruhi Initial Return Saham yang Listing di BEJ Tahun 1990-1997”. Kumpulan Makalah Simposium Nasional Akuntansi III. Google Scholar.

Firth, M., \& C.K. Liau-Tan. 1998. "Auditor Quality, Signaling, and The Valuation of Initial Public Offerings". Journal of Business Finance and Accounting 25. (1 \& 2). Jan/ Mar. Google Scholar.

Giri, Efraim F. 2010. "Pengaruh Tenur Kantor Akuntan Publik (KAP) dan Reputasi KAP terhadap Kualitas Audit: Kasus Rotasi Wajib Auditor di Indonesia”. Purwokerto: Simposium Nasional Akuntansi XIII. Google Scholar.

Grinblatt, M and Hwang, C.Y. 1989. "Signaling and Pricing New Issues" Journal of Finance”. No 44. Google Scholar.

Gujarati, D.N. 1995. "Basic Econometrics". McGraw-Hill International Edition. Third Edition. Google Scholar.

Hanafi, Mamduh \& Suad Husnan. 1991. "Perilaku Harga Saham di Pasar Perdana". Usahawan. No. 11 Tahun XX.November. Google Scholar.

Mayangsari, Sekar. 2003. "Pengaruh keahlian dan independensi terhadap pendapat audit: Sebuah kuasieksperimen". Jurnal Riset Akuntansi Indonesia Vol.6 No.1 (Januari). Google Scholar. 
Meutia, Intan. 2004. "Independensi auditor terhadap Manajemen Laba untuk KAP Big 5 dan non Big 5". Jurnal Riset Akuntansi Indonesia, Vol. 2 No. 1, Januari, hal. 37-52. Google Scholar.

Suyatmin dan Sujadi. 2006. "Faktor-Faktor yang Mempengaruhi Underpricing pada Penawaran Umum Perdana di Bursa Efek Jakarta". Jurnal ekonomi BENEFIT Vol. 10 No. 1 Hal. 11-32. Google Scholar.

Syamsudin, Lukman. 2004. "Manajemen Keuangan Perusahaan (Konsep Aplikasi Dalam Perencanaan, Pengawasan, dan Pengambilan Keputusan)". Jakarta: PT. Raja Grafindo Persada. Google Scholar.

Widiyanti, \& Kusuma. 2013. "Analisis Informasi Akuntansi dan Non Akuntansi Terhadap Initial Return Saham pada Perusahaan yang Melakukan IPO Di Bursa Efek Indonesia". Manado: SNA XVI. Google Scholar.

Yasa, G. W. (2008). "Penyebab Underpricing pada Penawaran Saham Perdana di Bursa Efek Jakarta". Jurnal Ilmiah Akuntansi dan Bisnis Vol.3 No.2, 145-157. Google Scholar. 